\title{
EFEK BENTUK FISIK RANSUM TERHADAP EFISIENSI PENGGUNAAN PROTEIN PADA AYAM BROILER
}

\author{
(The Effect Physical Form of Diet on Protein \\ Utilization of Broiler)
}

\author{
Indra Panjaitan, Ma'ruf Tafsin ${ }^{1}$ dan Zulfikar Siregar ${ }^{2}$ \\ 1 Mahasiswa Program Studi Peternakan Fakultas Pertanian Universitas Sumatera Utara \\ 2 Staf Pengajar Program Studi Peternakan Fakultas Pertanian Universitas Sumatera Utara
}

\begin{abstract}
Diet physical form could influence the diet utilization of broiler. The aim of this research was to study the effect physical form of diet on protein utilization in broiler diet. The method that was used to determine the efficiency of protein utilization was by calculating the protein retention and protein efficiency ratio. The experiment used completely randomized design with 5 treatments and 3 replications. The treatments composed of P1 (mash), P2 (fine crumble), P3 (crumble), P4 (coarse crumble) and P5 (pellets). The results of this research showed that physical form of diet gave significantly different effect on the protein retention $(\mathrm{P}<0.05)$ but did not give significantly effect on the protein efficiency ratio $(\mathrm{P}>0.05)$. The Highest protein retention of the diet on starter phase was mash $(94.23 \%)$ and the lowest was crumble $(92.34 \%)$ while the highest protein retention finisher phase was coarse crumble (92.71\%) and the lowest was pellet $(92.10 \%)$. It can be concluded that the starter diet can use mash or fine crumble while the finisher diet phase can use a coarse crumble or pellet.
\end{abstract}

Keywords: Physical ration, protein retention, protein efficiency ratio, broiler

\begin{abstract}
ABSTRAK
Bentuk fisik ransum dapat berpengaruh terhadap pemanfaatan protein ransum pada ayam broiler. Penelitian ini bertujuan untuk mengetahui pengaruh bentuk fisik ransum terhadap efisiensi penggunaan protein dalam ransum ayam broiler. Metode yang dilakukan untuk menentukan efisiensi penggunaan protein adalah dengan cara menghitung retensi protein dan rasio efisiensi protein. Rancangan penelitian yang digunakan adalah rancangan acak lengkap dengan 5 perlakuan dan 3 ulangan. Perlakuan yang diuji tersusun atas P1 (tepung), P2 (fine crumble), P3 (crumble), P4 (coarse crumble) dan P5 (pellet). Hasil penelitian menunjukkan bahwa efek bentuk fisik ransum memberikan pengaruh berbeda nyata $(\mathrm{P}<0,05)$ terhadap retensi protein tetapi tidak berpengaruh nyata terhadap rasio efisiensi protein $(\mathrm{P}>0,05)$. Retensi protein tertinggi pada fase starter diperoleh tepung $(94,23 \%)$ dan terendah diperoleh crumble $(92,34 \%)$ sedangkan pada fase finisher ransum berbentuk coarse crumble menunjukkan hasil yang sama dengan ransum berbentuk pellet. Dapat disimpulkan bahwa ransum fase starter dapat menggunakan tepung atau fine crumble sedangkan ransum fase finisher dapat menggunakan coarse crumble atau pellet.
\end{abstract}

Kata kunci: Fisik ransum, retensi protein, rasio efisiensi protein, broiler

\section{PENDAHULUAN}

Ayam pedaging merupakan salah satu komoditi ternak unggas yang dapat diandalkan untuk kebutuhan protein hewani masyarakat. Hal ini disebabkan kemampuannya untuk berkembang dengan cepat dan harganya terjangkau oleh daya beli masyarakat. Tingkat kesejahteraan dan tingkat pendidikan masyarakat sangat berpengaruh terhadap pola konsumsi yaitu dari pemenuhan karbohidrat menjadi protein. Sehingga permintaan akan protein hewani 
akan meningkat seiring dengan kemajuan teknologi dan tingginya tingkat pendapatan, salah satu upaya dalam memenuhi kebutuhan tersebut adalah dengan meningkatkan produksi unggas baik pedaging maupun petelur. Bahan ransum yang berasal hewani memiliki banyak keunggulan dibanding dengan bahan ransum yang berasal dari tumbuh-tumbuhan, karena mengandung asam amino yang lengkap dan lebih mudah diserap oleh tubuh. Dengan demikian maka kebutuhan akan bahan makanan yang berasal dari hewani terus meningkat terutama kebutuhan masyarakat akan protein hewaninya yang mencapai $15 \mathrm{~kg} / \mathrm{kapita} / \mathrm{tahun}$.

Peternakan ayam broiler pada masa sekarang ini sangat populer. Awalnya peternakan ayam broiler berkembang hanya di pulau Jawa (sekitar tahun 1980-an), hal ini disebabkan semakin majunya teknologi maka diperoleh bibit ayam broiler yang berkembang di daerah tropis seperti Sumatera Utara. Oleh karena itu sekarang ini usaha peternakan ayam broiler telah ditemukan disetiap provinsi. Hingga kini ayam broiler telah dikenal masyarakat Indonesia dengan berbagai kelebihan seperti hanya dengan 5 sampai 6 minggu ayam sudah dapat dipanen. Dengan waktu pemeliharaan yang relatif singkat ini akan lebih menguntungkan. Beberapa mamfaat yang dapat diperoleh dengan membuka usaha ayam broiler ini diantaranya untuk usaha ekonomi kerakyatan mandiri, mendapatkan daging konsumsi dan kotorannya dapat digunakan sebagai pupuk tanaman.

Ternak broiler mempunyai pertumbuhan yang cepat, konsumsi ransum yang efisien dan biaya produksi yang lebih murah. Salah satu faktor yang menentukan efisien tidaknya produksi ternak adalah jumlah ransum yang dikonsumsi untuk memproduksi satu kilo gram berat badan yang biasa disebut konversi ransum, semakin kecil rasionya berarti semakin efisien produksi ternak tersebut. Namun biaya ransum merupakan biaya terbesar dalam suatu usaha peternakan yaitu sekitar 60-70\% berasal dari ransum dan selebihnya berasal dari biaya produksi lainnya seperti biaya vaksin, dan obat-obatan. Untuk menekan biaya ransum yang tinggi, perlu adanya usaha-usaha yang efisiensi dalam pemanfaatan ransum oleh ternak, supaya peningkatan pendapatan dapat dicapai sesuai yang diharapkan. Salah satu upaya yang dapat dilakukan untuk memperbaiki efisiensi ransum adalah pemilihan bentuk partikel size ransum yang disesuaikan dengan umur dari broiler (Axe, 2000).

Ada beberapa variasi bentuk fisik ransum yang dapat diberikan pada ayam broiler yaitu tepung (all mash), remah (crumble), dan pellet. Secara naluri, ayam broiler lebih menyukai ransum yang berbentuk butiran. Meskipun demikian, dalam menentukan ransum yang dihasilkan akan lebih efisien penggunaanya, perlu dikaji lebih lanjut khususnya yang menyangkut pengaruh ukuran bentuk fisik ransum yang digunakan selama periode 
pemeliharaan (Lindblom, 2008). Hal inilah yang mendasari penulis untuk meneliti pengaruh dari bentuk fisik ransum terhadap efisiensi penggunaan protein terhadap ayam broiler.

\section{BAHAN DAN METODE}

\section{Lokasi dan Waktu Penelitian}

Penelitian dilaksanakan di Laboratorium Biologi Ternak, Program Studi Peternakan Fakultas Pertanian Universitas Sumatera Utara, Medan dengan ketinggian $\pm 25 \mathrm{~m}$ diatas permukaan laut. Penelitian ini berlangsung selama 54 hari mulai tanggal 14 Oktober sampai tanggal 3 Desember 2011.

\section{Bahan dan Alat Penelitian}

\section{Ternak}

Jenis strain ayam broiler yang dipakai dalam penelitian ini adalah Lohman 202 yang diberi nama strain New Lohman MB 202 umur 35 hari sebanyak 18 ekor. Dimana 15 ekor digunakan untuk mengetahui nilai kecernaan protein ransum kemudian 3 ekor lainnya digunakan untuk mengetahui nilai protein endogenus. Bobot badan ayam broiler yang digunakan adalah $1708,78 \pm 52,83$ gram.

\section{Ransum}

Ransum yang digunakan adalah ransum komersil yang diproduksi PT. Indojaya Agrinusa (Group PT. Japfa Comfeed Indonesia, Tbk) yaitu ransum dengan merk dagang BR I dan BR II dimana ransum BR 1 terdiri dari Mash (tepung), Fine Crumble, Crumble, dan ransum BR II Coarse Crumble, dan Pellet .

\section{Kandang dan Perlengkapan}

Kandang yang digunakan pada saat pengumpulan sampel untuk penentuan retensi protein, rasio efisiensi protein penggunaan ransum broiler adalah kandang metabolis berukuran 50 x 45 x $45 \mathrm{~cm}$ sebanyak 18 buah. Masing-masing kandang terdiri dari 1 ekor broiler. Kandang ini dilengkapi dengan tempat air minum serta plastik penampung ekskreta. Peralatan lain yang digunakan adalah timbangan digital, oven $60^{\circ} \mathrm{C}, \mathrm{H}_{2} \mathrm{SO}_{4} 0.01 \mathrm{~N}$, label, sendok dan kantong plastik. Alat penerang/ pemanas berupa lampu pijar 40 Watt sebanyak 
15 buah. Kabel sepanjang sebagai bagian instalasi dari alat penerang/ pemanas. Termometer sebagai alat untuk mengukur suhu ruangan.

\section{Metode Penelitian}

Rancangan penelitian yang digunakan adalah rancangan acak lengkap (RAL) dengan 5 perlakuan 3 ulangan dan sehingga diperoleh 15 susunan perlakuan.
a) P1 = Ransum starter berbentuk Tepung
b) P2 = Ransum starter berbentuk Fine Crumble
c) P3 = Ransum starter berbentuk Crumble
d) P4 = Ransum finisher berbentuk Coarse Crumble
e) P5 = Ransum finisher berbentuk Pellet

\section{Parameter Penelitian}

\section{Retensi Protein}

Persentase retensi protein dapat diperoleh dengan menghitung selisih protein yang dikonsumsi dengan protein ekskreta yang kemudian dibagi dengan konsumsi protein yang hasilnya dikalikan 100\% (Scott et al., 1982).

$$
\mathrm{RP}=\frac{\mathrm{KP}-(\mathrm{PE}-\mathrm{PEn})}{\mathrm{KP}} \times 100 \%
$$

\footnotetext{
Keterangan :

RP : Retensi Protein (\%)

KP : Konsumsi Protein (g/ekor)

PE : Protein Ekskreta (g/ekor)

PEn : Protein Endogenus
}

\section{Rasio Efisiensi Protein (REP)}

Anggorodi (1994) menyatakan rasio efisiensi protein diperoleh dengan cara menghitung pertambahan bobot badan dibagi dengan konsumsi protein kemudian dikali dengan $100 \%$. Konsumsi protein diperoleh dengan jalan persentase kandungan protein (dari hasil analisis proksimat) dikalikan dengan konsumsi bahan keringnya.

$$
\mathrm{REP}=\frac{\mathrm{PBB}}{\mathrm{KP}} \quad \mathrm{x} 100 \%
$$

Keterangan :

REP : Rasio Efisiensi Protein (\%)

PBB : Pertambahan Bobot Badan (g)

KP : Konsumsi Protein $(\mathrm{g})$ 


\section{Pelaksanaan Penelitian}

\section{Pengacakan Broiler}

Broiler terlebih dahulu ditimbang, diambil standar defiasinya, diacak, kemudian dimasukkan ke dalam setiap plot kandang dengan tujuan untuk memperkecil nilai keragaman.

\section{Pemeliharaan}

Perbedaan perlakuan terdapat pada bentuk fisik ransum yang dikonsumsi Mash, Fine Crumble, Crumbel. Coarse Crumble dan pellet). Sebelum penelitian dilakukan pemuasaan dilakukan terhadap semua perlakuan selama 24 jam. Selama penampungan ekskreta dan endogenus dilakukan penyemprotan $\mathrm{H}_{2} \mathrm{SO}_{4}$ 0,01 N sekali dalam dua jam. Penyemprotan ini dilakukan agar nitrogen sebagai bagian dari protein tidak menguap sehingga data protein ekskreta yang diperoleh benar-benar akurat. Selama penelitian semua ternak mendapatkan perlakuan yang sama, setiap hari selama empat hari ternak mengonsumsi ransum sebayak 120 gram/ekor.

\section{Analisis Data}

Data yang diperoleh dianalisis berdasarkan sidik ragam. Bila hasil analisis ragam menunjukkan perbedaan maka akan dilakukan uji lanjut dengan metode Beda Nyata Jarak $(\mathrm{BNJ})$.

\section{HASIL DAN PEMBAHASAN}

Rekapitulasi hasil penelitian tentang efek bentuk fisik ransum terhadap efisiensi penggunaan protein pada ayam broiler tersaji pada Tabel 1 .

Tabel 1.Rekapitulasi Hasil Penelitian

\begin{tabular}{ccccc}
\hline \multirow{2}{*}{ Perlakuan } & \multicolumn{4}{c}{ Rataan } \\
\cline { 2 - 5 } & $\begin{array}{c}\text { Konsumsi } \\
\text { protein(g) }\end{array}$ & $\begin{array}{c}\text { Retensi Protein } \\
\text { Kasar (\%) }\end{array}$ & PBB & $\begin{array}{c}\text { Rasio Efisiensi } \\
\text { Protein }\end{array}$ \\
\hline $\begin{array}{c}\text { Periode } \text { starter } \\
\text { P1 }\end{array}$ & 26,39 & $94,23^{\mathrm{a}} \pm 0,14$ & 71,38 & $270,33^{\mathrm{tn}} \pm 136,63$ \\
P2 & 25,59 & $92,46^{\mathrm{ab}} \pm 0,11$ & 66,05 & $258,33^{\mathrm{tn}} \pm 15,47$ \\
P3 & 25,91 & $92,34^{\mathrm{b}} \pm 1,02$ & 62,16 & $240,00^{\mathrm{tn}} \pm 20,79$ \\
\hline Periode finisher & & & & \\
P4 & 23,09 & $92,71^{\mathrm{ab}} \pm 1,10$ & 47,97 & $207,67^{\mathrm{tn}} \pm 78,68$ \\
P5 & 23,44 & $92,10^{\mathrm{b}} \pm 0,33$ & 44,64 & $190,69^{\mathrm{tn}} \pm 51,52$ \\
\hline
\end{tabular}

Keterangan : Superskrip yang berbeda pada kolom yang sama menunjukkan perbedaan yang nyata (P$<0,05)$ 


\section{Retensi Protein}

Retensi protein kasar dapat diperoleh dengan menghitung selisih konsumsi protein kasar ransum dengan protein kasar yang diekskresikan setelah dikoreksi dengan protein kasar endogenus. Hanifiasti et al. (2006) menyatakan bahwa semakin sedikit protein kasar yang dibuang bersama ekskreta, maka akan meningkatkan nilai daya cernanya.

Selama penelitian semua ternak mendapatkan perlakuan yang sama, setiap hari selama empat hari ternak mengonsumsi ransum sebanyak 120 gram/ekor. Iqbal et al. (2012) menyatakan bahwa pembatasan ransum diharapkan mampu mengefisiensikan penggunaan protein. Konsumsi protein diperoleh dengan jalan persentase kandungan protein (dari hasil analisis proksimat) dikalikan dengan konsumsi keringnya.

Rataan retensi protein kasar ransum tertinggi pada tabel. 1 yang diperoleh dari hasil penelitian pada perlakuan P1 yaitu sebesar 94,23 $\pm 0,14$ dan terendah pada perlakuan P5 sebesar 92,10 $\pm 0,33$. Berdasarkan analisa sidik ragam diketahui bahwa efek bentuk fisik ransum memberikan pengaruh yang nyata $(\mathrm{P}<0,05)$ terhadap retensi protein kasar ransum pada ayam broiler.

Perbedaan antara perlakuan terhadap retensi protein kasar ayam broiler dilakukan dengan uji BNJ. Sehingga uji fisik ransum broiler pada fase starter diketahui bahwa perlakuan P1 berbeda nyata dengan P3 tetapi berbeda tidak nyata dengan P2. Sedangkan pada fase finisher perlakuan P4 tidak memberi pengaruh yang berbeda nyata terhadap P5.

Salah satu kondisi ransum diantaranya ukuran bentuk fisik ransum yang pada akhirnya dapat mempengaruhi penformans (konsumsi ransum, pertambahan bobot badan dan konversi ransum) ayam dan efisiensi dari penggunaan suatu ransum (penyerapan protein/nitrogen dan energi metabolisme dan efisiensi ekonomis) (CPI, 2006). Berdasarkan hasil penelitian diketahui bahwa semakin kecil ukuran ransum semakin tinggi rataan retensi proteinnya.

Jadi dengan perbedaan bentuk fisik ransum akan mempengaruhi retensi protein kasar suatu ransum, dimana dapat diketahui bahwa pada fase stater ransum bentuk fisik tepung dan fine crumble lebih efisien dalam penggunaan protein kasar dibandingkan dengan ransum berbentuk crumble sedangkan pada fase finisher ransum coarse crumble tidak memiliki perbedaan yang nyata terhadap pellet. 


\section{Rasio Efisiensi Protein (REP)}

Rasio efisiensi protein kasar diperoleh dengan cara menghitung pertambahan bobot badan dibagi dengan konsumsi protein kasar kemudian dikali dengan 100\%. Pertambahan bobot badan disebabkan oleh ketersediaan asam amino pembentuk jaringan sehingga konsumsi protein kasar ransum berhubungan langsung dengan proses pertumbuhan. Artinya bahwa protein yang berkulitas baik akan meningkatkan pertambahan berat badan setiap unit protein yang dikonsumsi (Hanafiasti et al., 2006).

Rasio efisiensi protein tertinggi pada tabel 1. terdapat pada perlakuan P1 yaitu sebesar $270,49 \pm 136,63$ dan yang terendah pada perlakuan P5 yaitu sebesar 190,49 $\pm 51,52$. berdasarkan analisis sidik ragam diketahui pengaruh efek ukuran bentuk fisik ransum tidak berpengaruh nyata terhadap rasio efisiensi protein.

Rasio efisiensi protein yang menunjukkan hasil tidak berbeda nyata $(\mathrm{P}>0,05)$ mempunyai keterkaitan dengan hasil konsumsi protein dan pertambahan bobot badan ( $P>0,05)$. Nuraini (2009), menyatakan bahwa jumlah ransum yang dikonsumsi menentukan besarnya pertambahan bobot badan yang dihasilkan. Lebih lanjut Mahfudz et al. (2010) menyatakan bahwa rasio efisiensi protein (REP) dipengaruhi oleh dua hal yaitu Pertambahan Bobot Badan (PBB) dan konsumsi protein. Pertambahan bobot badan yang hampir sama disebabkan oleh pemenuhan kebutuhan hidup kurang terpenuhi, karena keterbatasan nutrisi dan energi.

Konsumsi protein yang tidak berbeda dikarenakan jumlah konsumsi ransum yang sama, konsumsi yang sama menyebabkan pertambahan bobot badan yang hampir sama dan bobot badan yang hampir sama di akhir pemeliharaan menyebabkan rasio efisiensi protein tidak berbeda. Hal ini sesuai dengan pernyataan Iqbal et al. (2012), yang menyatakan bahwa jumlah konsumsi protein berpengaruh terhadap pertambahan bobot badan, ini disebabkan karena pertambahan bobot badan tersebut berasal dari sintesis protein tubuh yang berasal dari protein.

Jadi perbedaan bentuk fisik ransum tidak mempengaruhi rasio efisiensi protein (REP) suatu ransum, dimana dapat diketahui bahwa rasio efisiensi protein (REP) pada fase starter ransum bentuk fisik tepung tidak berbeda dengan ransum berbentuk fine crumble, crumble dan pada fase finisher rasio efisiensi protein ransum coarse crumble juga tidak berbeda dengan pellet. 


\section{KESIMPULAN}

Bentuk fisik ransum ayam broiler memberikan pengaruh nyata terhadap retensi protein tetapi tidak berpengaruh nyata terhadap rasio efisiensi protein. Pada ransum fase starter, tepung dan fine crumble menunjukkan nilai retensi protein yang lebih tinggi dibandingkan crumble. Sedangkan untuk ransum fase finisher ransum betuk coarse crumble menunjukkan retensi protein yang sama dengan pellet.

\section{DAFTAR PUSTAKA}

Anggorodi, R. 1994. Nutrisi Aneka Ternak Umum. Gramedia Pustaka Utama, Jakarta.

Axe, D.E, PhD. 2000. Feed Production and Technology Manual. IMC AGRICO Feed Ingredients, Illionis USA.

CPI (Charoen Pokhpan Indonesia). 2006. Pengaruh Partikel Size Ransum terhadap Performans Broiler Komersial. Charoen Pokphan Indonesia Jakarta.

Hanifiasti, W., Shanti, L. Sutarno. (2006). Daya Cerna Protein Pakan, Kandungan Protein Daging, dan Pertambahan Berat Badan Ayam Broiler setelah Pemberian Pakan yang Difermentasi dengan Effective Microorganisms-4 (EM-4). Bioteknologi 3 (1): 17-18.

Iqbal, F., Atmomarsono, U. dan Muryani, R. 2012. Pengaruh Berbagai Frekuensi Pemberian Pakan dan Pembatasan Pakan terhadap Efisiensi Penggunaan Protein Ayam Broiler. Animal Agricultural 1 no 2: 4-5.

Lindblom, J.A. 2008. Feed Technology and Nutrition Workshop. 16th Annual ASA-IM Southeast Asian, Singapore.

Mahfudz, L.D., T.A. Sarjana, dan W. Sarengat. 2010. Efisiensi penggunaan protein ransum yang mengandung limbah destilasi minuman beralkohol (ldmb) oleh burung puyuh (coturnix coturnix japonica) jantan. Prosiding. Seminar Nasional Teknologi Peternakan dan Veteriner. Fakultas Peternakan, Universitas Diponegoro.

Nuraini. 2009. Penformans Broiler dengan Ransum Mengandung Campuran Ampas Sagu dan Ampas Tahu yang Difermentasi dengan Neurospora Crassa. Media Peternakan 32 No 3: $3-5$.

Prawitasari, R.H., V.D.Y.B. Ismadi dan I. Estiningdriati. 2012. Kecernaan Protein Kasar dan Serat Kasar Serta Laju Digesta pada Ayam Arab yang Diberi Ransum dengan Berbagai Level Azolla microphylla. Animal Agriculture Journal, 1. No. 1:3-7.

Scott, M.L., M.C. Neishem dan R.J. Young. 1982. Nutrient of The Chicken $4^{\text {th }}$ Ed. M.L. Scott and Associates. Ithaca. New York. 